\title{
ZASOBY ARCHIWUM KURII METROPOLITALNEJ W KRAKOWIE
}

Ważna * dla potrzeb badawczych inwentaryzacja zespołów krakowskiego Archiwum Kurii Metropolitalnej (AKM) jest sprawą równie pilną, co długoterminową, jeśli myśleć o jej pełnej realizacji. Niektóre bowiem archiwalia wymagają jeszcze uporządkowania, zaś opracowanie całości długo jeszcze zastępowane będzie katalogami częściowymi lub tymczasowymi. Bieżące potrzeby związane $z$ udostępnianiem zbiorów wymagają jednak zebrania informacji o podstawowych zespołach AKM, ich charakterze, narastaniu i ewidencji, aby zarówno ułatwić korzystanie z nich, jak również, by przygotować rodzaj wstępu do przyszłych inwentarzy. Szczegółowość tych ostatnich z natury rzeczy przypomina wykaz drzew, a nie całościowy ogląd lasu potrzebny na początek.

\section{A. NAJSTARSZE ZESPOEY ARCHIWALNE}

Powołane do bytu przez Kodeks Prawa Kanonicznego kurie biskupie nowego typu gromadzą $\mathrm{w}$ wyniku swego działania pisma napływające i kopie własnych, co tworzy narastający ciągle zespół archiwalny, dzielący się rzeczowo według agend urzędu. W archiwach diecezjalnych przechowywane są jednocześnie zamknięte już zespoły akt odziedziczonych po poprzednich organach władzy kościelnej.

W okresie przedrozbiorowym biskupi rzadko przebywając w stolicy diecezji rządzili nimi zarówno za pomocą towarzyszącej im wraz z dworem (kuria) kancelarii, jak i poprzez rezydujących na miejscu wikariuszy generalnych, pełniących często funkcje oficjałów, a posługujących się

* Wykaz skrótów nazw zbiorów archiwalnych i niektórych wydawnictw ciągłych występujących w tekście i przypisach artykułu: Aadm - Acta administratoria; ABMK - Archiwa Biblioteki i Muzea Kościelne; AEp - Acta episcopalia; AGr Acta gratiosa; AKK - Archiwum Kapituly Katedralnej w Krakowie; AKM Archiwum Kurii Metropolitalnej w Krakowie; AOf - Acta officialia; ArD Archiwum Diecezjalne; AV - Acta visitationis consistoria [in AKM]; AVCap Acta visitationis capituli [in AKM]; PSB - Polski Słownik Biograficzny. 
własną kancelarią, tj. konsystorzem generalnym. Pod koniec XVIII w. $\mathrm{w}$ diecezjach łączono kancelarię generalnego oficjała $\mathrm{z}$ kurią biskupią w jeden urząd zwany aż do $1917 \mathrm{r}$. konsystorzem biskupim, generalnym lub ordynariatem. Dotychczasowe archiwa wytworzone biskupów i oficjałów generalnych połączone zostały w jedno przechowujące, zwane najczęściej konsystorskim ${ }^{1}$.

Obok zmian organizacyjnych decydujących o wyodrębnieniu zespołów archiwalnych istotnym wyznacznikiem klasyfikacji jest sama kancelaryjna postać aktu. Średniowieczne kancelarie aż do końca XIV lub początku XV w. nie pozostawiały u siebie żadnych śladów sporządzenia dokumentu, gromadząc jedynie dyplomy obcego wystawcy. Zmiana tej praktyki polegająca na zaprowadzeniu rejestracji czynności własnych kancelarii, a to w postaci stosowanych w XIV-XVIII w. tzw. ksiąg wpisów, zdecydowała o początku zasobu aktowego narastającego odtąd systematycznie przy urzędach, zamiast dotychczasowego rozproszenia u rozmaitych odbiorców. Wychodzące na zewnątrz pisma przestały już byé jedynymi dowodami dokonania czynności prawnej, tracąc z czasem na znaczeniu wobec możliwości uzyskania wyciągu z ksiąg wpisów, stanowiących rodzaj kopiariusza dokumentów ekspediowanych czy przedstawionych do wpisu, tj. oblatowanych. W drugiej połowie XVIII w. system ksiąg wpisu był stopniowo wypierany na rzecz protokołu czynności, gdzie akta porządkowano według czynności kancelarii. Czwartym etapem rozwoju form kancelaryjnych był stosowany do dziś, a wypracowany przez rozwiniętą biurokrację państw zaborczych, system akt sprawy, grupujący materiał aktowy nie wokół czynności urzędu, lecz wokół załatwianej sprawy, podług ewidencji dziennika podawczego.

Okres kancelarii odbiorcy $\mathrm{w}$ polskich diecezjach charakteryzuje się gromadzeniem dokumentów (również dotyczących biskupstwa) w archiwum kapituły katedralnej i to nawet po założeniu przez ordynariuszy własnych kancelarii i archiwów ${ }^{2}$. W tych ostatnich ${ }^{6}$ zaczęto gromadzić rejestry odbywanych czynności administracyjnych i sądowniczych, niekiedy przekazywane $\mathrm{z}$ czasem do składnicy konsystorskiej. Konsystorz jako drugi urząd terytorialno-jurysdykcyjny przechowywał przede wszystkim własną produkcję aktową w postaci analogicznych do akt biskupich kopiariuszy, określanych jako acta consistorii lub acta officialia ${ }^{3}$.

1 H. E. W y c zaw ski, Polskie archiwa kościelne, w: Księga tysiąclecia katolicyzmu w Polsce, cz. 2, Lublin 1969, 86-87; S. Pła za, Źródła rękopiśmienne do dziejów wsi $w$ Polsce feudalnej. Studium archiwoznawcze, Warszawa 1976, 175.

2 J. Szymański, Nauki pomocnicze historii od schytku IV do końca XVIII w., Warszawa 1972, 371-382; A. Tom czak, Kancelaria biskupów włocławskich w okresie księgi wpisów (XV-XVIII w.), „Rocz. Tow. Nauk. w Toruniu” 69 (1964) z. 3 , s. $6-7,234$; H. W y c z a w s k i, jw., 57-59.

3 Oficjał nie będący wikariuszem generalnym prowadził odrębnie swoją kancelarie. Por. H. W y c z a w s k i, jw., 68-69. 
Redagowano je tak, jak episcopalia, ingrosując kolejno wszystkie czynności urzędu, których sąsiedztwo wpisu wynikało jedynie ze wspólnej daty: dokonania. Niekiedy zakładano kilka równoległych ksiąg dla poszczególnych rodzajów spraw.

Niezależnie od stopnia zróżnicowania ksiąg kurialnych czy konsystorskich, podstawowy fakt, że były prowadzone równocześnie, zmusza do dwutorowej kwerendy, gdyż większość spraw mogła być prowadzona przez którąkolwiek z obu kancelarii. Mimo szerszych uprawnień samych biskupów zastrzegających sobie najważniejsze decyzje, oficjalaty generalne ze względu na stałość miejsca urzędowania w stolicy diecezji załatwiały więcej spraw niż kurie, wytwarzając też więcej akt.

Ze śmiercią czy translacją biskupa kończyło się urzędowanie kurii i konsystorza, a władzę w diecezji przejmował wikariusz kapitulny, zwany w Polsce administratorem ${ }^{4}$. Dokumentacja jego kilkumiesięcznych lub paruletnich rządów zawarta jest w Acta administratorialia.

\section{AKTA KANCELARII ORDYNARIUSZA}

1. Acta episcopalia (AEp) rejestrują czynności biskupa, ilustrując sposób sprawowania przezeń władzy w diecezji i władzy patrymonialnej $\mathrm{w}$ dobrach stołowych. Biskup wydawał szereg zarządzeń dla duchowieństwa i poddanych, instytuował na beneficja, potwierdzał nowe fundacje itd. Przedmiotem wpisu był pełny tekst wystawianego dokumentu lub relacja o dokonanej czynności prawnej. W tej drugiej postaci redagowano większość zapisek ilustrujących etapy przewodu sądowego, $z$ którego do indukty wnoszono głównie materiał dowodowy i wyrok. W AEp notowane są również zeznania w sprawach niespornych, jak rezygnacja $\mathrm{z}$ beneficjów kościelnych, umowy stron, kwitowanie długu, darowizny na rzecz instytucji kościelnych. Przyjmowano też oblatowane dokumenty, tak dla potwierdzenia treści (transumpty), jak i tylko dla jej utrwalenia. Notariusze zamieszczali też $z$ własnej inicjatywy wzmianki rozmaitej treści dotyczące wydarzeń w kraju, diecezji czy na dworze biskupa. Sporadycznie odnotowywano korespondencję wchodzącą i wychodzącą ${ }^{5}$.

Większość ksiąg episkopaliów zawiera zapisy ogółu wymienionych wyżej aktów prawnych biskupa, wynikających z jego duchowej i dominialnej władzy ${ }^{6}$. Część jednak woluminów poświęcona jest sprawom określonego typu. I tak istnieją osobne:

4 Tamże, 65, 68.

5 T e ṅ̇e, Wprowadzenie do studiów $w$ archiwach kościelnych, Warszawa 1956, 116-137; A. Tomczak, jw., 186-204. Treść krakowskich AEp nie odbiega od zawartości AEp z Włocławka.

6. AEp w zasadzie nie służyły rejestracji czynności biskupa jako senatora i osoby prywatnej. 
- Acta institutionum (akta instytuowania na beneficjach) biskupów: Konarskiego (t. 8-9/1514-1521, 1522-1524), Tomickiego i Latalskiegc (t. 14/1532-1536), Gamrata (t. 22/1538-1545) ${ }^{7}$, S. Maciejowskiego (t. 27, cz. 2/1546-1550);

- Acta privilegiorum, erectionum, dotationum (współczesne i transumowane akta erekcyjno-fundacyjne) biskupów: Konarskiego (t. 10/15191524), Tomickiego (t. 14 do 1524), Gamrata t. 23 do 1545), S. Maciejowskiego (t. 27 do 1550);

- Acta fori saecularis (akta świeckiej władzy) biskupów: Radziwiłła (t. 34/1592-1600, Księstwo Siewierskie), B. Maciejowskiego (t. 37/1600 1606), Zadzika (t. 51/1636-1640) ${ }^{8}$;

- Attestationes seu depositiones testium (zeznania świadków) przed sądem bpa Gamrata (t. 24/1538-1541);

- Acta gratiosa (AGr), czyli dyspensy i pozwolenia.

Ostatni dział wymaga szerszego potraktowania ze względu na niekonsekwencje dotychczasowego zaszeregowania. Trzy tomy tych akt wliczone są bowiem do episkopaliów (AEp 98-99/1759-1782 bpa Sołtyka i 112/1782 - 1791 bpa Poniatowskiego), pozostałe natomiast tworzą osobną serię ${ }^{9}$.

Cztery woluminy AEp (100, 101, 113, 122) stanowią Protocolla, czyli bruliony właściwych episkopaliów, do których zostały włączone zapewne $z$ powodu niesporządzenia czy zagubienia indukty.

Niektóre tomy AEp z drugiej połowy XVIII w. noszą w tytułach określenie localia lub vialia $(95,100-102,104-111)$, z przewagą tych pierwszych. Nie ma to jednak wpływu na merytoryczne treści akt, poza lokalizacją dokonanych czynności.

Serię episkopaliów, rozpoczynającą się aktami bpa Jana Lutka z Brzezia pod datą $31 \mathrm{~V} 1466 \mathrm{r}$., należy zamknąć na t. 122, ostatnim prowadzo-

Z Zob. A. Tomczak, jw., 206.

Nadto w AEp 64 (Trzebickiego) wydzielono część (k. 440-479v, 1663-73) dla tego działu.

${ }_{9}$ Dopiero W AGr wprowadzono rejestrację prawie nie uwzględnianych dotąr typowych spraw mniejszej wagi i krótkiego okresu ważności, jak np. czasowe aplikowanie wikariusza do parafii, aprobata do słuchania spowiedzi czy udzielanie jednorazowych uprawnień. Pierwsze trzy tomy AGr Załuskiego z 1746-55 (brak t. z 1749, jak wynika z Inwentarza z 1758 zob. przyp. 85) zawierają oprócz dyspens i aprobat ogólne rozporządzenia ordynariusza, instrukcje dla wizytatorów, przeznaczone dla Rzymu relacje kilku poprzedników Załuskiego (zob. S. P ła za, Źródła, 233). Bardziej standartowy zakres treści prezentują AGr Sołtyka z 1759-64 oraz konsystorza z 1776-80 i 1783-97, stanowiące bruliony. Z warszawskiej kancelarii prymasa Poniatowskiego, jako administratora diecezji krakowskiej pochodzą AGr z 1786-87 i 1788-90; nadto istnieją woluminy z 1768-90, 1791-95 (konsystorskie), 1791-1800, 1793-94 oraz Indeks zestawiający mechanicznie spisy treści tomów z 1746-91. Kolejne woluminy, zaczynajac od Protocollum expeditionum in gratiosis administratora diecezji Józefa Olechowskiego z 1800-03, przechodzą na formę zbliżoną do systemu akt sprawy (11 t. z XIX w. i 7 tek pism petentów), by stopniowo przyjąć postać dziennika podawczego. 
nym systemem ksiąg wpisów, a zawierającym Acta curiae episcopalis bpa Feliksa Turskiego z lat 1797-1800. Spośród tych 122 woluminów zachowało się 116. Po wojnie zaginęły: cenny t. 2 ze źródłami do dziejów obyczajów i walki z reformacją 10; t. 40, 45 i 47 z aktami świeckimi Księstwa Siewierskiego z czasów bp. Tylickiego, Szyszkowskiego i Wazy; takiż t. 51 bpa Zadzika, odnoszący się nadto do innych miast biskupich; a także t. 57, Gembickiego, z lat 1652 - 20 VI 1653 r. ${ }^{11}$

2. Acta administratoralia (Aadm), prowadzone w okresie wakatów biskupstwa krakowskiego, są rejestrami czynności wykonanych przez lub w imieniu kolejnych wikariuszy kapitulnych, w przewidzianym przez prawo kanoniczne zakresie ${ }^{12}$. Dział ten jest wyodrębniony niecałkowicie, gdyż zdarzało się, że notariusz administratora kontynuował księgę zmarłego biskupa, a jeśli nim został ów tymczasowy rządca diecezji prowadził niekiedy dotychczasową. I tak akta Jana Rzeszowskiego, administratora (1471-72), a następnie biskupa, mieszczą się w trzecim tomie AEp (od k. 61 właściwe AEp). Aadm 1-5 to akta Jerzego Myszkowskiego (1535-36), Tomasza Rożnowskiego (1538), 2 tomy Andrzeja Czarnkowskiego (1545-46) i Jana Przerembskiego (1550-51). Tom 6 zawiera akta Marcina Izdbieńskiego z 1572 i Łukasza Podoskiego z $1577^{13}$, a t. 7 Jana Tarnowskiego z 1591 r.

Sufragan Paweł Dembski, rządzący diecezją po śmierci kard Radziwiłła (1600) i powtórnie, po przeniesieniu Maciejowskiego do Gniezna (1606-07) zostawił trzy tomy akt (8, 9, 9a), z których ostatni to Acta Ducatus Severiae (1606-07). Dla spraw fori saecularis wydzielono osobne części ksiąg kolejnych administratorów: Andrzeja Lipskiego (1616) ${ }^{14}$ i Piotra Gembickiego $(1631-32)^{15}$.

10 Decreta submissionis et alia vitam et mores personarum tam spiritualium quam saecularium tangentia continentur 1510-82. Z tomu tego korzystał jeszcze ks. Glemma, nie zna go już Katalog z 1956 r. Zob. przyp. 11, 23, 59.

11 Inwentarz z 1824, zob. S. 491. Wzmiankowane w literaturze 122 tomy AEp nie dowodzą kompletności serii, lecz świadczą o ustalaniu liczebności na podstawie skrajnych sygnatur; por. Ordynacje i ustawy wiejskie $z$ archiwów metropolitalnego i kapitulnego $w$ Krakowie $1451-1689$, opr. S. K u r a ś, Kraków 1960, s. V; S. P łaza, Źródła, 230; Wypisy źródłowe do dziejów Wawelu z archiwaliów kapitulnych $i$ kurialnych krakowskich 1440-1500, opr. B. Przy byszewski, Kraków 1960, s. VII.

12 Dlatego słusznie pozostawiono wśród AEp księgi tych biskupów, którzy z różnych przyczyn mimo objęcia rządów nie uzyskiwali tytułu episcopus Cracoviensis, lecz administrator z dodatkowymi określeniami. Chodzi tu o Radziwiłła i Poniatowskiego - AEp 33-34, 113-119.

1:3 Z tłoczonego na okładce napisu wynika, że w księdze miano prowadzić od 1577 r. tom 2 akt bpa Krasińskiego, zmarłego 16 III t. r., co świadczy o zamiarz rychłego sporządzenia indukty.

14 Aadm 10, s. 401-422. Zamieszczono tu nadto akta Księstwa Siewierskiego z początku rządów bpa Szyszkowskiego (s. 423-443).

15 Aadm 11, s. $1025-1137 ; 12$, s. $1393-1523$. 
Aadm 13, Szymona Kołudzkiego z 1635 r., stanowią właściwie kontynuację AEp 46 z lat 1633-35, kiedy pod nieobecność młodego kard. Wazy delegowany przezeń Kołudzki rządził diecezją ${ }^{16}$.

Kolejnymi administratorami osieroconej diecezji byli dwaj zasłużeni dla niej sufragani: Tomasz Oborski (t. 14/1642) i jego bratanek Mikołaj (t. $15 / 1657-58 ; 16-17 / 1680-81)^{17}$. Tom 18 (1699-1701) zawiera akta wikariusza kapitulnego Kacpra Cieńskiego oraz oficjała generalnego Kazimierza Eubieńskiego, który zostawszy administrotorem kontynuował akta swej działalności w t. 19-23 w latach $1702-08{ }^{18}$.

Następnym tymczasowym rządcą diecezji był sufragan przemyski Stanisław Hozjusz (t. 24/1719-20), a po nim dwukrotnie Michał Wodzicki (t. 25/1732-33, 26/1746-47). Sufragan Franciszek Potkański administrując w 1759 r. został oficjałem generalnym za Sołtyka, a jego akta wpisywano w tym samym tomie (AOf 191). Na tym należy zakończyć opis serii ksiąg Aadm ${ }^{19}$.

3. Wizytacje. Zasada proweniencji wymaga, by protokoły powizytacyjne zailczać do zespołu akt biskupa, gdyż ten chociaż sam rzadko fatygował się odbywaniem wizytacji, to jednak wykonywano ją z jego mandatu ${ }^{20}$. Wizytatorzy, często kanonicy katedralni, składali nierzadko akta tej lustracji w archiwum kapitulnym ${ }^{21}$. Dlatego zbiór ksiąg wizytacyjnych diecezji krakowskiej, należący do największych w Polsce, rozbity jest między AKM i Archiwum Kapituły (AKK). Większość akt wizytacji $z$ tego ostatniego przeniesiono przed kilkunastu laty do AKM jako depozyt, pozostawiając na Wawelu prawie wyłącznie tomy odnoszące się do katedry ${ }^{22}$.

Jedne z najstarszych, jakie przechowały się w Polsce, protokoły wizy-

16 Charakter jego kompetencji, jako episcopatus Cracoviensis in spiritualibus et temporalibus deputati, spowodował, że AEp 46 nie zaliczono do akt wikariuszy generalnych (funkcję tę pełnił oficjał Erazm Kretkowski) ani administratorów, lecz zatytułowano Acta actorum Joannis Alberti [...] Prowadzono je do 27 I 1635 , tj. jeszcze blisko miesiąc po śmierci kardynała, zanim nie nadeszła o tym wieść z Padwy. Por. T. Now a k, Jan Albert Waza, PSB X $422-423$.

17 Aadm 17 od s. 851 stanowi kontynuację akt M. Oborskiego jako generalnego wikariusza i oficjała z $1682 \mathrm{r}$.

18 T. 22 jest właściwie brulionem.

10 Sygnaturę 27 nosi niedbale pisany terminarz akt Józefa Olechowskiego (1800-04), zaś 28 - Ludwika Łętowskiego (1841-59), który mimo tego zaszeregowania i tytułu stanowi kopiariusz rozporządzeń ogólnych.

20 H. W y c zaw ski, Polskie archiwa, 67; S. Płaza, jw., 232; S. Librowski, Wizytacje diecezji włocławskiej, z. 1: Wstęp ogólny do wizytacji, ABMK 8 (1964), 133-135.

21 Omawianie ogólnie znanych walorów źródłowych wizytacji można w krótkim szkicu zastąpić odsyłaczem do najważniejszych opracowań; zob. S. L i b r o wski, jw.; S. Litak, Akta wizytacyjne parafii $z$ XVI-XVIII w. jako źródto historyczne, "Zeszyty naukowe KUL" 5 (1962) nr 3, 41-58; H. W y c z a w ski, Wprowadzenie, 79 n., 144 n.

2:2 Sygnatury tych zdeponowanych w AKM akt poprzedza się skrótem AVCap, a konsystorską grupę wizytacji - AV. 
tacji przeprowadzonej w diecezji za rządów bpa Padniewskiego pochodzą z lat $1565-70$ i obejmują mniej niż połowę parafii ${ }^{23}$.

Bardziej systematycznej wizytacji dokonano za czasów kard. Radziwiłła (1591-1600), który brał osobiście udział w tej pracy, odwiedzając część klasztorów i znaczniejsze kościoły w Krakowie i w terenie ${ }^{24}$. Wśród delegowanych przezeń wizytatorów wyróżnił się prepozyt tarnowski, a od 1599 r. biskup kijowski Krzysztof Kazimirski. W latach 1595-98 wizytował on aż 31 dekanatów na 45, z których zachowały się akta ${ }^{25}$. Wizytację kontynuowano za bpa Maciejowskiego (1600-06) ${ }^{26}$, kontrolując jednocześnie wykonanie rozporządzeń z poprzedniej wizytacji (decreta reformationis) podczas zebrań duchowieństwa kilku dekanatów, zwoływanych w tym celu do większych parafii, np. do Olkusza, Oświęcimia, Pilzna. Praktykę tę utrzymano również za bpa Tylickiego (1607-16), wizytując nadto 31 dekanatów, w tym 6 dwukrotnie ${ }^{27}$.

Kolejną akcję wizytacyjną rozwinięto za rządów bpa Szyszkowskiego (1616-30), poddając tej kontroli co najmniej 40, tj. niemal $80 \%$, dekanatów i to przed odbyciem synodu diecezjalnego w r. $1621{ }^{28}$. Większą część zadania wykonał archidiakon krakowski Jan Fox, odwiedzając 22 dekanaty ${ }^{29}$. Z czasów bpa Zadzika (1635-42) przetrwały trzy tomy wizytacji 11 dekanatów ${ }^{30}$, a z czasów Gembickiego (1642 - 57) — tyleż to-

23 AVCap 1. Zagubione AEp 2 zawierały relacje o przedtrydenckich wizytacjach dyscyplinarnych z 1510 -53; zob. przypis 10; T. G le mma, Wizytacje diecezji krakowskiej $z$ lat 1510-1570, „Nasza Przeszłość” 1 (1946), 46-53, 57-60; J. B uk ow ski, Dzieje reformacji w Polsce, t. 1, Kraków 1883, 165-178.

24 AV 2, AVCap 9. Nadto w AKK poszyt z XVI-XVIII w. (sygn. 64) zawiera glownie kopie wizytacji katedry i pojedynczych kościołów, gdzie fragmenty akt, m. in. Radziwiłła, Szaniawskiego i Załuskiego. Wydania fragmentów wizytacji wylicza S. Płaza (Źródla drukowane do dziejów wsi $w$ dawnej Polsce. Studiuri bibliograficzno-źródłoznawcze, Kraków 1974, 191 n.).

${ }_{25}$ W tym dla 4 dekanatów - Oświęcim, Nowa Góra, Skawina i Zator - przetrwały tylko skrócone protokoły, zregestowane wraz z pozostałymi $w$ jednym tomie (AVCap 65). Pozostałe sygn.: AVCap 2, 4 (inna redakcja 2), 5, 7, 10, 12, 14, 15, 68; $\mathrm{AV} 1,3,8$.

26 AVCap. 19 i 19b (brulion i indukta, katedra - w AKK), 20-23 (15 dekanatów). Nadto w ArD w Lublinie - wizytacja archidiakonatu lubelskiego, tj. 5 dekanatów z 1603 - Kat Mikr. nr 2, s. 179 (Katalog mikrofilmów Ośrodka Archiwów, Bibliotek $i$ Muzeów Kościelnych przy Katolickim Uniwersytecie Lubelskim, opr. B. Kumor nr 1: ABMK 6, 1963, s. 67-153; nr 2: tamże 13, 1966, s. 171-268; nr 3: tamże 24, 1972, s. $173-277$; nr 4: tamże 31, 1975, s. 283-380). W zestawieniach nie uwzględniono, poza katedrą, pojedynczych parafii ujętych sporadycznie w niektórych protokołach, co i tak nie zmienia ogólnego obrazu aktywności wizytacyjnej.

27 Decreta executiva: 1601-05 (21 dekanatów - AV 4), 1608 (17 dekanatów AVCap 27); wizytacje: AVCap 24-25 (kopia - AV 5), 26, 28-32.

ys Jedynie AVCap 42 dotyczy 6 dekanatów wizytowanych powtórnie w $1629-34$. D:ecezja liczyła 51 dekanatów w 1621 r. - B. K u mor, Granice metropolii $i$ cliecezji polskich (966-1939), ABMK 18 (1969), 352.

29 Osobiście pisał protokoły wizytacji, umieszczając w osobnych woluminach dane visitationis externae et internae - AVCap 33, 35, 38, 40, 41; pozostale wizytacje: AVCap 34, 36, 37 (niepełna kopia 39); AV 6 (współoprawne z późniejszymi).

30 W tym katedry i kilku kościołów krakowskich - AVCap 43, 44, 56; zob. E. Wiśniewski, Czas sporzq̨dzenia wizytacji nr 56 w AKM, ,Sprawozdania z Czynności Wydawniczych Towarzystwa Naukowego KUL" 12 (1961) 80-81. 
mów dla 11 takich okręgów ${ }^{31}$. Zachowane protokoły wizytacji odprawionych z polecenia bpa Trzebickiego (1658-79) dotyczą 23 dekanatów ${ }^{32}$, Małachowskiego (1681-99) - $7^{33}$, Eubieńskiego, jako administratora i biskupa (1702-19) - $20^{34}$, Szaniawskiego $(1720-32)-34^{35}$, Lipskiego $(1732-46)-11^{36}$.

Najpełniejsza dokumentacja zachowała się do wizytacji odbytej za bpa Załuskiego w latach 1747-48 (Kraków 1748-51) - 21 tomów protokołów z 36 dekanatów ${ }^{37}$, a także 12 ksiąg tabelarycznego zestawienia danych wizytacyjnych dla 47 dekanatów ${ }^{38}$. Z czasów bpa Sołtyka (1759-82) pozostały akta wizytacji 12 dekanatów ${ }^{39}$, tyleż po Poniatowskim (1782-91) ${ }^{40}$, i z dwóch dekanatów po Turskim (1791-1800) ${ }^{41}$. Przetrwały również protokoły wizytacji 1792 r. z 5 dekanatów, należących wówczas do diecezji tarnowskiej ${ }^{42}$; materiał ujęto tam częściowo w formie tabel, podobnie jak wizytację dekanatu Książ z 1807 r.43. Jeszcze bardziej od tradycyjnego układu protokołu wizytacyjnego odbiegają akta dekanatu kieleckiego z 1830 r., stanowiące poszyt przygotowanych uprzednio w parafiach opisów kościołów, rachunków, życiorysów plebanów ${ }^{44}$.

31 W tym 2, Oświęcim i Zator, wizytowano dwukrotnie. Nadto w ArD w Lublinie wizytacje archidiakonatu lubelskiego z 1644 i 1650 , a w AKK inwentarz kościoła w Urzędowie - Kat. mikr. nr 2, 179.

32 W tym 2, Kije i Tarnów, wizytowano dwa razy, a zator - trzykrotnie. Eącznie z zasobami ArD w Kielcach i Lublinie zachowały się akta 26 dekanatów, w tym czterech wizytowanych dwa razy - AV 6, 8-11; AVCap 47-50, 54, 51-53 (katedra, 1670) - AKK; Kat. mikr. nr 2, 175, 179.

33 Z czego 2, Urzędów i Zawichost, wizytowano trzykrotnie, Opatów - dwa razy (dla tych 3 dekanatów inwentarze wizytacji $1689 \mathrm{r}$. W AKK, sygn. 7). W ArD w Lublinie wizytacja archidiakonatu lubelskiego z 1694-1711 - AV 12-14; AVCap 55, 57; Kat. mikr. nr 2, 180.

34 AV 15-18; AVCap 58, 59 (kopia 1 dekanatu z AV 17), 63; w AKK, sygn. 63 - katedra i inne kościoły krakowskie; zob. przyp. 33.

$35 \mathrm{Z}$ tego 13 na początku, reszta głównie pod koniec rządów, kiedy wizytowal przeważnie sufragan Michał Kunicki - AV 6 i 11 (czéść), 20-22, 23 (wtórnik AVCap 61); AVCap 60; wizytacja katedry i kilku kolegiat - AKK, bez sygn.

36 Nadto w ArD w Lublinie akta 4 dekanatów, a w ArD w Kielcach - 3 (w tym 2, Bodzanów i Kunów - duplikat AV 27) - AV 24-27; AVCap 61 (1 dekanat); Kat. mikr. nr 1, 83, 176; nr 2, 180.

${ }^{37}$ W ArD w Lublinie - z dalszych 2 dekanatów, w ArD w Kielcach - 1 (dublet AV 31). Dekanat Wojnicz był wizytowany powtórnie w $1754-\Lambda \mathrm{V} 28-47$; AVCap 62, 67; Kat. mikr. nr 2, 180; nr 1, 83.

${ }_{38}$ Tabella eorum super quibus in visitatione inquirendum est. Materiał wizytacyjny każdej z uwzględnionych parafii rozpisany został w 140 rubrykach; zob. S. Litak, Struktura $i$ funkcja parafii $w$ Polsce, w: kościót $w$ Polsce. Wieki XVI- XVIII, Kraków 1969, 272-275.

39 AV 48-57. Nadto W ArD w Kielcach i Lublinie akta 4 dekanatów - Kat. mikr. nr 1, 83; nr 2, 180 .

46) AV $53-57$

41 AV 59.

42 Oświęcim, Zywiec, Wojnicz - dekrety reformacyjne (AV 58, 60), Wadowice, Myślenice (bez sygn). Nadto 2 kopie protokolu wizytacji parafii Zubrzyca (wowczas diecezja spiska) z 1794 i 1820.

$43 \mathrm{AV} 62$.

44 AV 63. 
Ostatnie, podobnie jak następne akta wizytacji odbywanych na innych zasadach, należy traktować oddzielnie. Utrudnienia stawiane przez władze zaborcze wizytacjom kanonicznym, potrzeba szybkiej informacji żądanej przez gubernium i stan ciągłej sprawozdawczości, kwitnącej zarówno za czasów związku diecezji z Królestwem Polskim, jak i w Galicji - podnosiły rangę raportów dziekańskich i proboszczowskich odpowiedzi na konsystorskie kwestionariusze ${ }^{45}$. Ta nowoczesna forma gromadzenia danych nie była przecież absolutną nowością. Staropolskie instrukcje, dawane wizytatorom, stanowiły także kwestionariusz, którego partie, np. inwentarz, wypełniane były uprzednio przez plebana i ingrosowane przez notariusza wizytatora, choć ten ostatni i tak nie był w stanie sprawdzić całości ustnej relacji rządcy parafii.

4. Księgi czynności pontyfikalnych w AKM stanowią rejestry funkcji sakralnych, pełnionych przeważnie przez biskupów pomocniczych, zwanych sufraganami, którzy częściej od ordynariuszy udzielali święceń, bierzmowali, konsekrowali kościoły, ołtarze, kielichy i dzwony ${ }^{46}$. Najstarsze trzy jednostki formalnie nie należą do tej grupy, gdyż są to Księgi examinis ordinandorum archidiakona krakowskiego Stanisława Krasińskiego $\mathrm{z}$ lat $1573-1614^{47}$.

Liber ordinatorum, censecrationis ecclesiarum, capellarum, altarium, portatilium ${ }^{48}$ z lat 1646 - 72 zawiera akta sufraganów Wojciecha Lipnickiego i Mikałaja Oborskiego, którego rejestr funkcji kontynuowany jest w t. 3 (1673-94). T. 4 stanowi wykaz czynności pontyfikalnych sufraganów Stanisława i Michała Szembeków (1695-1726); t. 5 - administratora, potem ordynariusza, Eubieńskiego (1706-18); t. 6 - administrującego wakującą diecezję sufragana przemyskiego Stanisława Hozjusza (1719-20) i bpa Konstantego Szaniawskiego (1720-32). Osobna księga mieści Acta pontificia kard. Lipskiego (1734-45). T. 7 stanowi dokumentację działalności sufragana Michała Kunickiego (1727-_45); t. 8 Franciszka Potkańskiego (1753-89); następny Dominika Kiełczewskiego,

45 Taki charakter nosi już sporządzony przez kapitułę w odpowiedzi na kwestionariusz bpa Turskiego Status ecclesiae cathedralis Cracoviensis cum responsis ad questici ir ordine ad visitationem z 1792 - AKK (egzemplarz łacinski i polski).

46 Formalnie biorąc należałoby rozdzielić tę serię między akta kancelarii biskupiej, sufıaganów i - przy księgach egzaminów przed święceniami - archidia. konów, co jrz: słabo rozbudowanym lub szczątkowym charakterze tych ostatnich i rzeczowej jedności wszystkich 3 działów uznałem za niewskazane; nadto pontyfikalne funkcje niektórych ordynariuszy notowane w AEp nie dadzą się nawet fizycznie wydzielić. Por. A. Tomczak, Kancelaria, 26, 188; M. Wyczawski, Polskie archiwa, 68.

${ }_{47}$ Tomy 1-2 (1573-96) przechowywane były do niedawna w AKK, od t. 3 zaczynała się, i to już wg inwentarza z 1824, seria omawianych ksiąg w obecnym AKM. Dalej podaję sygnatury dotychczasowe, ich brak oznacza depozyt AKK W AKN.

${ }_{48}$ Taką samą numerację zawierają karty tytułowe większości następnych tomów. Inne określenia: Acta pontificalium functionum - Hozjusza, Acta functionum episcopalium - Olechowskiego, Woronicza, Łętowskiego. 
sufragana chełmskiego, działającego (1761-74), podobnie jak Hozjusz, w diecezji krakowskiej; kolejny - Józefa Olechowskiego (1786-1805), a następnie ordynariuszy: Andrzeja Gawrońskiego (t. 9/1805-13), Jana Woronicza (t. 10/1816-23) i Karola Skórkowskiego (t. 12/1830-35). Nadto istnieją księgi: Tomasza Nowińskiego, generała bożogrobowców z Miechowa, wyręczającego bpa Woronicza (t. 11/1816-29), Ludwika Eętowskiego (1845-62), administratora diecezji i Jana Puzyny (1886-1910) z wykazem funkcji pełnionych tak na sufraganii lwowskiej, jak i na stolicy biskupiej w Krakowie.

Czynności pontyfikalne ordynariuszy wpisywano często nie $\mathrm{w}$ osobne rejestry, lecz do AEp. Nawet zestawienie kart incipitowych, gdzie zamieszczono te wykazy, świadczy o różnym stopniu aktywności poszczególnych biskupów w osobistym wykonywaniu władzy święceń ${ }^{49}$. Brak wspomnianych wykazów mógł w pojedynczych wypadkach wynikać nie z zaniechania pełnienia omawianych funkcji, lecz $z$ zagubienia księgi lub zaniedbania wpisu ${ }^{50}$.

5. Varia gromadzone w kancelarii biskupiej zestawić można razem, gdyż niewielka ich ilość i różnorodny charakter przemawiają przeciw formalnemu rozdrabnianiu ${ }^{51}$.

Przejrzystymi, ujętymi tabelarycznie źródłami są: Descriptio ecclesiarum parochialium in Dioecesi Cracoviensi parte Cisvistulana consistentium z 1776 r. i przeprowadzony z polecenia prymasa Poniatowskiego w 1787 r. spis ludności diecezji krakowskiej bez jej byłej części galicyjskiej ${ }^{52}$. Akta majątkowe biskupstwa i inwentarze pałacu biskupiego, przechowywane w większości w AKK, zostały tam ostatnio scalone. Kopiarz Edicta et mandata dioecesis Cracoviensis zawiera rozporządzenia ordynariuszy z lat 1737-55. Przyłączonej do Austrii w wyniku I rozbioru części diecezji dotyczy cenny zbiór korespondencji bpa Soltyka z gubernium lwowskim z 1773 -8153. Bruliony AEp zostaną, dla uni-

4. Krasiński — t. 30, k. 22v, 42, 398, 412, 607v; Myszkowski — t. 31, k. 525v; Radziwilł - t. 32 , k. 7v; t. 33, k. 279; Zadzik - t. 48, k. 97v, 305, 737; t. 49, k. 232; Gembicki - t. 52, k. 235; Trzebicki — t. 59, k. 205v, 360, 392v, 537; t. 60, k. 737 ; t. 64, k. 57 ; t. 65, k. $628 \mathrm{v}, 634 \mathrm{v}, 663 \mathrm{v}, 670$; Małachowski - t. 67, k. 67, 342; t. 68, k. $69 \mathrm{v}, 231,437,474,478,581,605 \mathrm{v}, 789,940 ;$ t. 69, k. $296,425,467,578,743$, 891, 941, 1030, 1224; t. 70, k. 8, 51, 269, 294, 313, 331, 380, 394, 442, 453, 474, 547, 549, 556; t. 71, k. 254; t. 72, k. 26; Soltyk - t. 99, k. 656v.

50 $\mathrm{Na}$ udzielanie święceń przez bpa Załuskiego wskazują zapiski w księgach klasztornych, dotyczące własnych ordynandów. Np. Liber rerum variarum scitu dignorum et memorabilium conventus Rupellanis 1658-1772 odnotowuje święcenia paulinów 25 i 28 XI 1751, udzielone przez ordynariusza w kościele franciszkanów (Archiwum Paulinów w Krakowie, sygn. 9, s. 263).

51 Por. A. Tom c zak, Kancelaria, 225-226.

32 Wydal go J. Kleczyński w "Archiwum Komisji Historycznej PAU" 7 (1894), 269-478; por. S. P ł a z a, Źródła rękopiśmienne, 234.

53 Prothocollum correspondentiae [...] loci ordinarii Cracoviensis cum excelso Gucernio Leopoliensi, t. 1: 1773-74; 2: 1775-76; 3: 1777-78; 4: 1779-80; 5: 1781. Trudno dociec, dlaczego autor dobrego studium tematu wylicza tylko 4 tomy, 
knięcia powtórzeń, omówione przy zespole konsystorza, który przechował ich dla własnych serii archiwalnych znacznie więcej.

\section{AKTA KONSYSTORSKIE}

1. A cta officialia (AOf) - to wspólna i nieścisła nazwa przemieszanych, a uszeregowanych chronologicznie akt dwu kancelarii - wikariusza in spiritualibus i oficjała generalnego. Nierzadkie łączenie w jednym ręku obu tych funkcji, równoległe prowadzenie w kancelarii konsystorskiej kilku rodzajów ksiąg, częste kontynuowanie ich przez notariuszy kolejnych wikariuszy generalnych i oficjałów, a wreszcie niezręczność kompaktorów i niekonsekwencja twórców istniejącego układu sygnatur - powodują względną tylko synchronizację tych ostatnich z latami, jakich dotyczą ${ }^{54}$.

Dwa podstawowe działy AOf, to: (a) właściwe akta sądowe oficjała Acta actorum officialia ${ }^{55}, 31 \mathrm{ksiąg}$, prowadzonych oddzielnie w latach 1433-57, 1474-1569, z paru kilkuletnimi przerwami; a następnie 100 woluminów z 1569-1796 pisanych łącznie z (b) aktami wikariuszy generalnych - Acta actorum vicarialia, które posiadają osobne 26 tomów z okresu 1475-1669. Pozostałe 4 wydzielone podserie dotyczą kilku etapów sądownictwa oficjała: (c) potwierdzenia stawienia się na rozprawę Pronuntiationes, 16 tomów z 1410-12 (najstarsza z ksiąg AOf) i 1509-67 (z kilku przerwami) ${ }^{56}$; (d) ustanawianie pełnomocników stron procesowych - Constitutiones procuratorum, 9 tomów z 1421-25, 1509-4957; (e) zobowiązania zwrotu pożyczki - Obligationes, 11 tomów pochodzących z 1440-1540 (z przerwami) ${ }^{58}$; (f) wyroki - Sententiae, 10 tomów prowadzonych od 1493 do 1540 (prócz lat 1527-37) ${ }^{59}$.

Poza wymienionymi okresami działy b-f prowadzone były razem z oficjaliami, co przy powszechnym łączeniu spraw sądowych i admini-

a mikrofilmowaniu Ośrodka ABMK poddano tylko 3 tomy - S. Grodziski, Gubernium lwowskie a kuria krakowska po pierwszym rozbiorze Polski, "Analecta Cracoviensia" 7 (1975), 325; Kat. mikr. nr 4, 306.

${ }^{54} \mathrm{Na}$ osobne prowadzenie ksiąg dla poszczególnych rodzajów spraw nie zwrócił uwagi I. Polkowski, traktując zespół AOf jako jednorodny i dziwiąc się, że akt $z$ jednego roku trzeba szukać w różnych woluminach. - Archiwum konsystorza krakowskiego, „Czas”, nr 138 z 19 VI 1879.

55 Rozbudowane zazwyczaj i zróżnicowane określenia kart tytułowych, występujących nieregularnie w XV-XVI w., wyliczają przeważnie typy spraw i pozostałe godności kościelne oficjała.

${ }_{36}$ W tym 3 tomy $(4,46,49)$ wspólne z aktami podserii d.

57 Nadto 3 tomy jak w przyp. 56.

58 Prócz tego 3 tomy wspólne $\mathrm{z}$ innymi podseriami: t. $28,53-\mathrm{f}, 46-\mathrm{c}$, d.

59 W tym t. 28 i 53 wspólnv, jak w przypisie 58. Poszczególne etapy procesu W sądzie kościelnym - zob. Wypisy źródłowe do dziejów Wawelu 1501-1515, opr. Przybyszewski, Kraków 1965, s. XXVIII-XXXVII; H. W y c zawski, Wprowacizenie, 125-137; zestawienie działów AOf w oparciu o używany w AKM Tymczasowy katalog archiwum konsystorskiego w Krakowie, opracowany w 1956 przez. S. Kurasia na prawach rękopisu. 
stracyjnych w kancelariach diecezjalnych jest zrozumiałe, a tytułowe oznaczenie danej księgi - nie zawsze w pełni adekwatne ${ }^{60}$.

Liczba 206 sygnatur AOf zgadza się, mimo jednej luki, z ilością zachowanych woluminów ${ }^{61}$.

2. Terminarze i protokoły. Omówione wyżej akta (AOf, AEp i Aadm) stanowią czystopisy, a sięgający do nich badacze z reguly nie interesują się brulionami. Te można doceniać lub postponować porównując je $\mathrm{z}$ induktą.

Pierwszym śladem pracy notariusza są terminarze czynności kancelaryjnych - Terminaria actorum, służące ewidencji rozpoczynanych procesów sądowych z lapidarnym określeniem przedmiotu i terminu, skąd nazwa. Te agendy, pisane najczęściej w formie dudki, zapełniane po marginesy włącznie, służyły następnie do sporządzenia właściwego brulionu, zwanego protokołem - Protocollum actorum, z którego dobierano materiał przeznaczony do kaligraficznego indukowania ${ }^{62}$. Kryteria rządzące selekcją spraw $\mathrm{z}$ terminarzy do protokołów, a $\mathrm{z}$ nich do czystopisu, nie zawsze pokrywają się z dzisiejszą skalą ważności zagadnień. Czy miałoby to oznaczać niekompletność wszelkich kwerend źródłowych prowadzonych wyłącznie w oparciu o induktę? Odpowiedź jest zróżnicowana, gdyż zależy od rodzaju problematyki, jaką w całości lub w czesści wnoszono do czystopisu. Częste w protokołach marginesowe noty dla kaligrafa (scribatur, omittatur) pozwalają szybko zorientować się, jakie sprawy i kiedy były pomijane. Okazuje się bowiem, że poza induktą mogły się znaleźć również tak częste w AOf i AEp oblaty testamentów, procesy obyczajowe duchowieństwa, a nawet mniej ważne etapy przygotowawcze erekcji kościołów i inne. Nieco trudniej jest sprawdzać stosunek zawartości protokołów do treści niestarannie pisanych terminarzy. Sondażowa weryfikacja kilku tomów wykazuje spory nieraz odsiew spraw na tym etapie. Szersze studium porównawcze 3 faz rejestracji aktu, przy bogatej podstawie źródłowej wszystkich 3 typów ksiąg, wniosłoby cenne dane źródłoznawcze dotyczące zasobu AKM z okresu księgi wpisów ${ }^{63}$.

Niemały czas dzielił niekiedy powstanie aktu od jego rejestracji, jak świadczą zapiski kancelistów. Połowa protokołu konsystorskiego za lata

60 Iylna jest np. informacja tytułowa AOf 158 - Acta actorum et causarum fiscarii officialatus Cracoviensis z 1671-81. Księga bowiem zawiera nie tylko sprawy o nieuregulowane konsystorzowi należności, lecz także inne - karne oraz niesporne; por. S. Pła za, Źródła rękopiśmienne, 268, przyp. 478.

61 Brak t. 135 (VI 1651 - VI 1652), lecz dublowane sygn. 18a, Institutionum $1492-97$.

${ }_{62}$ Por. H. W y czawski, Wprowadzenie, 73; tenże, Polskie archiwa, 65; S. Librow ski, Wizytacje, 87 .

63. Część protokołów pisana jest bardzo starannie, a niektóre z nich zastąpiły brakujace indukty AEp. Odnosi się to również do Protocollum Cisvistulanum in Zakrzówek (21 X 1778 - 23 III 1781). Zob. W. Chotkowski. Historia polityczna Kościoła w Galicji za rządów Marii Teresy, t. 2 Kraków 1909, 16-17, 113-116, 193-194. 
1713-19 zredagowana została w 1723, a w 1721 r. skryba oddawal w kancelarii konsystorskiej ukończone przez siebie nieoprawne seksterny za lata 1692-93. Kolacjonowanie AEp z 1759-62 miało miejsce w 1771 r. ${ }^{64} \mathrm{~W} 1800 \mathrm{r}$. regens urzędników konsystorza kończył terminarz za 1795 r. ${ }^{65}$. Nic więc dziwnego, że zdarzyło się zagubienie terminarzy przed ich wykorzystaniem czy niesporządzenie protokołu ${ }^{66}$. W podobnej sytuacji radzono sobie kwerendą $\mathrm{w}$ zachowanym lotnym materiale aktowym, jakim były tzw. producta, o czym niżej ${ }^{67}$. Opóźnienia w indukowaniu akt i rozproszenie brulionów przed ich wykorzystaniem tłumaczą powstanie niejednej luki w czystopisie 68 .

Inwentarz z $1824 \mathrm{r}$. wylicza $66 \mathrm{t}$. protokolów do AOf z lat 1662-1795 oraz 77 t. do AEp i Aadm z lat 1676-1790, zaś lączna liezba terminarzy wg inwentarza $z$ polowy XIX w. wynosi 122 t. za lata 1662-1800. Czekaja one na opracowanie.

3. Producta - zachowane w postaci luźnych akt z XVII-XIX w. to melanż zarówno własnych akt konsystorza, nieco biskupich, jak i najwcześniejszych z zachowanych w AKM akt obcych. Całość stanowi przeważnie dokumentację różnych etapów postępowania procesowego, a więc punkty oskarżenia z prywatnego czy urzędowego powództwa, pozwy, zeznania świadków, odpisy wyroków itd. Ze spraw niespornych warto wspomnieć atesty $z$ egzaminów kandydatów do święceń, prezenty na beneficja czy korespondencję plebanów $\mathrm{w}$ sprawie angażowania wikariuszy. Oprócz mało znaczących urzędowych kopii rozwlekłych formuł, powtarzanych $w$ nieskończoność w AEp, AOf i Aadm, spotyka się tu cenny materiał źródłowy ukazujący, zwłaszcza w relacjach świadków czy konfesatach przychwyconych wagabundów, żywych ludzi, ich reakcje, mentalność, język. Producta należały do najmniej cenionych akt w kancelariach biskupiej i konsystorskiej, a kanceliści nie mogli sobie ciągle poradzić z uporządkowaniem tej masy papieru. Zdekompletowane i umieszczone w 382 tekach bez zachowania porządku rzeczowego i - oprócz

${ }_{64}$ Prot. cons. 1713-19, k. ostatnia; Term. cons. 1717-18, k. I; AEp 102-103, kk. ostatnie.

${ }_{65}$ T. Glemma, Krakowski konsystorz biskupi za czasów Andrzeja Rawy Garońskiego, „Nasza Przeszłość” 4 (1948), 228; por. przyp. 13.

66 Term. episc. 1696-97, s. 3 ma notatkę: „terminarium 1695 deest”. Na końcu Term. cons. 1671-73 spotykamy ,dialogowy" zapis: ,quaeritur utrum anni praesentis terminarium reliquum extet nec ne? R.: Non extat. Quaeritur ergo quare? R.: Quia per negligentiam d. Regentis periit". Term. cons. 1731-32 kończy się informacją o braku protokołu za okres 3 VII 1732 - 9 II 1733.

${ }_{67}$ Requiruntur nonnulla ad protocollum, ex repertis citationibus debent suppleri defectus (Term. cons. 1693, k. ostatnia); videatur in productis iuramentum super... (Term. cons., 27 X 1767); extractum - in productis (Prot. cons., 31 VII 1764).

$68 \mathrm{~W}$ postaci kilku kart zostawionych do późniejszego wypełnienia, a w razie jego niedokonania kasowanych niekiedy przekreśleniem stron, ich sklejeniem czy dopiskiem nihil deest itp. Por. A. Tom c zak, jw., 178. 
ostatnich, sięgających lat 20-tych XIX w. - także chronologicznego, wymagają pracochłonnego uszeregowania ${ }^{69}$.

4. Varia konsystorskie nie są łatwe do wydzielenia z powodu płynnej'granicy końca okresu księgi wpisów i połączenia tej kancelarii z biskupią, o czym niżej. Podstawowy dział tworzą tu rozmaite pomoce kancelaryjne w postaci formularzy, repertoriów i skorowidzów, które omawiam w części C. Specyficzną, bo uzależnioną od osoby rządcy diecezji, grupę akt stanowią relacje z lat 1784-87 i 1789 przesyłane co miesiąc do Warszawy prymasowi Poniatowskiemu w oparciu o sprawozdania konsystorzy foralnych w celach częściej informacyjnych niż po decyzję ${ }^{70}$. Sprawozdania dotyczyły nie tylko bezpośrednich czynności tych urzędów, lecz opierały się również na raportach dziekanów o ważniejszych wydarzeniach, jakie zaszły w parafiach (te - zachowane w Producta), co ukazuje terenowy partykularz z rzadkiej w źródłach lokalnej perspektywy. Wolumen inwentarzy 52 kościołów krakow`kich z 1797/98 r. z urzędowym oszacowaniem precjozów iuxta mandata Augustissimae Majestatis stanowi dokumentację do polityki kościelnej władz austriackich ${ }^{71}$.

\section{ZESPOEY SZCZĄTKOWE}

Różnymi drogami dostały się do AKM księgi nie posiadające dziś macierzystych archiwów, a częściej - wyrwane $\mathrm{z}$ nich.

Tom Acta actorum oficjałów kieleckich z $1551-1625$ stanowi jedyną księgę oficjalatu foralnego w AKM. Z archiwów dziekańskich znalazły się tu Acta decanatus Novi Montis, 1634-175772 i księga wizytacji dziekańskich prowadzonych w tymże dekanacie nowogórskim w $1751-55$ w celu sprawdzania realizacji zaleceń wizytacji generalnej Załuskiego.

Większą grupę tworzą często bardzo wczesne Libri baptisatorum, copulatorum et mortuorum, prowadzone łącznie lub oddzielnie, $\mathrm{z}$ reguły niekompletne. Są to metryki parafii

69 Uporządkowano, najprawdopodobniej w końcu XVIII w., sądowe producta z 1784-93 tworząc Liber productorum officiosorum et iudicialium w 7 dużych poszytach. Mała troska o akta luźne (zob. przyp. 85 i 98) cechowała nie tylko krakowskie kancelarie kościelne - por. A. To m c z a k, jw., 227, 229.

70 Relationes de causis et negotiis expeditis in officiis curiae. Odręczne pytania stawiane przez adresata na marginesach i towarzyszace im minuty odpowiedzi świadczą o nowej formie sprawowania władzy nad administrowaną diecezją, a treść pytań i poleceń ujawnia oświeceniowe inspiracje.

${ }^{71}$ Prothocollum conscriptionis inventariorum ecclesiarum urbis Cracoviae et suburbiorum.

72 Zob. J. Kracik, Najstarsze akta kongregacji dekanalnych w Archiwum Kurii Metropolitalnej w Krakowie, ABMIK 29 (1974), 261-272. 


$\begin{array}{ccc}\text { baptisatorum } & \text { copulatorum } & \text { mortuorum } \\ 1593-1634 & 1592-1641 & \\ 1611-1755 & 1618-1781 & \\ 1609-1784 & 1609-1784 & 1726-1785 \\ 1675-1762 & 1726-1746 & 1761-1776 \\ 1603-1776 & 1601-1776 & 1682-1776 \\ 1603-1778 & 1606-1786 & 1746-1786 \\ 1600-1748 & 1608-1739 & \\ 1610-1762 & 1610-1746 & 1761-1776 \\ 1586-1771 & 1758-1776 & 1730-1753\end{array}$

Bolechowice
Droginia
Dziekanowice
Nowy Targ
Polanka Wielka
Radziszów
Rybna
Szaflary
Wadowice

Z parafialnych archiwaliów znalazło się w AKM także kilka kopiariuszy XVIII-wiecznych nazywanych Libri munimentorum, iurium, privilegiorum itp., gdzie zebrano wynotowane głównie z AOf akta fundacyjne probostw i prebend, czasem sentencje sądowe sporów o uposażenie ${ }^{73}$. Spotyka się także XVII i XVIII-wieczne pojedyncze księgi statutów lub protokoły posiedzeń kolegiów prebendarzy (psałterzyści, penitencjarze) z kościołów Mariackiego i św. Barbary oraz inwentarze kilku kościołów krakowskich. Większą grupę tworzą akta luźne i księgi brackie kolegiaty św. Anny. Opracowanie wymienionych akt winno poprzedzić: ich scalenie lub zastąpić - ekstradycja ${ }^{74}$.

\section{B. NOWY SYSTEM KANCELARYJNY OD PRZEEOMU XVIII I XIX W.}

Nie można wskazać jednej daty zakończenia systemu księgi wpisów w kancelariach diecezji krakowskiej. Indukty bowiem AOf prowadzone sa do 1796, AEp - do 1800 r. Terminarium actorum kurii bpa Turskiego redagowane jest na sposób dawnego protokołu transumującego całe dokumenty lub ich regesty, a jednocześnie od 1797 r. pojawiają się konsystorskie Protocolla exhibitorum prowadzone w postaci dziennika podawczego z osobnym indeksem rzeczowym na niemieckich, później łacińskich, drukowanych formularzach ${ }^{75}$. Z kolei Protocollum konsystorza z 1813 r. pisane jest starym systemem. Równolegle sporządzane były, w trybie akt czynności, Raporta z sesji konsystorskich, zachowane. w wiąze $z$ lat $1797-1808^{76}$.

73 Do ich sporządzania zachęcał już synod bpa Maciejowskiego z 1601 r. W. A braham, Ustawodawstwo kościelne o archiwach, ,Archeion" 4 (1928), 3-4. ${ }_{74}$ Poza parafialną pertynencją zostaje Księga wiejska Polanki Wielkiej, 1562-1792 .

$751797 \mathrm{nn}$ : Geschäfftsprotokoll des bischöflichen Konsistoriums zu Krakau in West-Galizien; 1812: Protocollum negotiorum Consistorii episcopalis Cracoviensis in Galicia Occidentali.

${ }_{76}$ Podobnie zatytulowane fascykuly Raportów czynności konsystorza z 1814-30 czy kancerarii zadwornej Pasterza z 1829 - 30 noszą charakter dziennikow podawezych. 
Od czasu objęcia rządów diecezji w 1782 r. przez Poniatowskiego, akta biskupie nie są już dzielone na localia i vialia, a wystawiająca je kuria określana jest jako krakowska, bez związku z miejscem przebywania ordynariusza, zaś powstające w warszawskiej kancelarii księcia prymasa gratiosa noszą w tytule wyraźne określenie charakteru akt sporządzanych w sytuacji kumulowania 2 diecezji i nierezydowania ${ }^{77}$. Pewną wskazówkę dla ustalenia daty reorganizacji dawnych kancelarii diecezjalnych stanowi koncept pisma sufragana Potkańskiego, skierowanego do Poniatowskiego w $1784 \mathrm{r} .{ }^{78}$.

Wprowadzony pod koniec XVIII w. kancelaryjny system akt sprawy przyjął się w pełni w latach 20-tych XIX w. i, po kolejnych ulepszeniach, trwa do dziś. Podstawowa w tym systemie księga ewidencji wpły-wających spraw - dziennik podawczy, nosił za bpa Woronicza wdzięczna nazwę Wyrocznik czyli sentencjonarz, któremu towarzyszył Rejestr alfabetyczny wchodzacych dokumentów i postanowionych rezolucji, zaś oryginały akt ingrosowano w Dziennik czyli journal, względnie zszywano. Całość początkowo współoprawiano, później prowadzono oddzielnie. Wyrocznik przyjął wkrótce nazwę Dziennik, którą w latach 50-tych XIX w. zmieniono na Protokót czynności, w okresie powojennym Dziennik podawczy, zaopatrzony w oddzielne, coroczne skorowidze alfabetyczne.

Największej ewolucji uległy zasady porządkowania samych akt dzielonych na fascykuły czy teki w układzie rzeczowo-chronologicznym, np. personalia, seminarium, parafie, kongregacje dekanalne, szkolnictwo, dziesięciny, zakony, korespondencja $z$ władzami państwowymi itd. Wspólna dla jednej sprawy ilczba porządkowa wiedzie kwerendę od indeksu do księgi podawczej, a stąd do akt w odpowiednim dziale.

Do schematu tego najsłabiej przystaje etap ostatni z powodu rozbijania registratury na działy rzeczowe, gdzie o ile później akt nie przegrupowano, to i tak przy ich powstawaniu istniały sprawy nietypowe, jakie można szeregować alternatywnie, według przekonań zmieniających się kancelistów. Jedną z największych serii narastającego zespołu akt najnowszych stanowią kopie metryk zachowane dla znacznej części parafii od początku XIX w. do lat 80-tych, a następnie, już regularnie, od 1945 r. Wiązki akt wizytacji i sprawozdań dziekańskich z XIX i początku XX w. zastępują materiał nie odbywanych przez dłuższe okresy wizytacji biskupich. Teczki parafii zawierają materiał niejednolity rzeczowo i chronologicznie, głównie z XIX-XX w., z wyłączeniem spraw

7 Acta gratiosa datae Varsaviae alias eorum omnium quae pro dioecesi praesenti Cracoviensi ex cancellaria Varsaviensi cum propria subscriptione [...] Michaëlis Poniatowski episcopi Płocensis, coadiutoris cum plena iurisdictione Cracoviensis conscripta 1782-91 - AEp 112.

is Zob. przyp. 81. 
związanych z większą produkcją aktową, składaną, jak wspomniano, osobno. Również oddzielnie zebrano papiery osobiste, zresztą częściowo przemieszane z urzędowymi, biskupa-wygnańca Karola Skórkowskiego (Opawa 1835-1851) oraz kardynała Adama Stefana Sapiehy.

\section{NARASTANIE I PORZĄDKOWANIE ZASOBU}

\section{GROMADZENIE I PRZECHOWYWANIE AKT}

Konsystorz generalny i jego archiwum mieściły się przy ul. Kanoniczej, w domu zwanym ,Lisia Jama”, przedostatnim po prawej stronie patrząc w stronę Wawelu. Dom kupili w 1451 r. Jan Długosz z bratem, a po przebudowie odstąpili go za dziesięcinę i patronat nad altarią katedralna bpowi Tomaszowi Strzempińskiemu pro perpetuo consistoris officialatus Cracoviensis et pro conservatione regestrorum atque productorum ${ }^{79}$. To ostatnie określenie, niezależnie od nadawanego mu w XV w. zakresu znaczeniowego, świadczy, że już wtedy gromadzono nie tylko rejestry czynności własnych. Kancelaria konsystorska i archiwum zajmowały 2 izby na parterze, górne pomieszczenia służyły za mieszkanie dla pisarza, a niekiedy i domowników biskupa ${ }^{80}$.

Akta powstałe i gromadzone przejściowo w kancelarii biskupiej, głównie w Kielcach, przekazywano stopniowo do archiwum krakowskiego konsystorza, co zapewniało pełny wgląd w priora, niezbędny wszaks w urzędzie załatwiającym większość spraw diecezji ${ }^{81}$. Nadto archiwalia

79 J. Długosz, Liber beneficiorum, t. 1 Cracoviae 1863, 185-186; T. G l e m$\mathrm{ma}$, Krakowski konsystorz, 237; K. P i e r a d zka, Zwiqzki Dtugosza z Krakowem, Kraków 1975, 84. W inwentarzu z 1824 zanotowano: „druga kamienica po lewej ręce idąc z Zamku, niegdy Lisia Jama zwana, a potem przez Długosza na skład i chowanie regestrów czyli aktów diecezjalnych kupiona, imię konsystorskiego domu otrzymała".

so $\mathrm{Bp}$ Padniewski umieścił tam swego włodarza Piotra Chwalikowskiego, na co Kapituła zgodziła się pod warunkiem przyjęcia stanu duchownego przez lokatora. Zarządca biskupich dóbr ożenił się jednak, a mieszkanie przeznaczył bp Myszkowski w dożywocie swemu medykowi. Šwiadczy to o rodzaju współwłasności domu przez ordynariusza i Kapitułę - AEp 30, k. 686v-687; por. A. T o m c z a k, jw., 34-35 (o włodarzach); K. B ąk o w ski, Dom Dtugosza, Kraków 1897, 12; zob. przypis następny.

${ }_{81}$ Ważną informację zawiera fragment konceptu listu sufragana i oficjała Potkańskiego do rządcy diecezji, prymasa Poniatowskiego, z Krakowa 21 I 1784 (Producta, tecz. 17): ,Kamienica, w ktorej jest archiwum i więzienie nazwane Niedźwiedź, jest własna officii od wieków na to przez biskupów i Kapitułę destynowana. W niej jest archiwum aktów biskupich i konsystorskich. Nawet z Kielc akta tamtejsze tu bywają przewożone, bo tu jest archiwum generalne. W tejże kamienicy zawsze bywała kancelaria konsystorska i pisarz konsystorski zawsze w niej mieszkiwał. Ta kamienica jest na Kanoniczej ulicy, idąc z Zamku na lewej stronie druga w rzędzie, zaraz naprzeciwko moich okien, bo moja jest idąc z Zamku pierwsza na prawej ręce. Pokiej był konsystorz, tedy przez wszystkie czasy trzymałem kancelarię Curiae w mojej własnej kamienicy, ale teraz, gdy samo tylko jest officium Curiae, od Nowego Roku przewieziona jest do kamienicy rzeczonej archiwalnej, w której mieszka ks. pisarz, kanceliści i kursor". Wzmianka o przechowywaniu nie tylko akt ale i delikwentów znajduje potwierdzenie w AOf 
te były w konsystorzu bezpieczniejsze w epoce, kiedy dygnitarze panstwowi czy kościelni zwykli byli uważać akta piastowanych urzędów za prywatną własność, której po ich śmierci czy translacji trzeba było nierzadko szukać wśród spadkobierców lub w innej diecezji ${ }^{82}$.

Archiwalia mieściły się W „Lisiej Jamie” do pierwszej polowy XIX w., kiedy zagrożone wilgocią zostały zabrane z polecenia bpa Woronicza do pałacu biskupiego. Uratowane z pożaru w $1850 \mathrm{r}$. księgi przeniesiono na dawne miejsce, skąd przed remontem kamienicy przetransportowano je znów do nieodrestaurowanej jeszcze w pełni rezydencji biskupiej ,do jednej, szczupłej, ciasnej i źle zabezpieczonej izby", gdzie pozostawały bez opieki. Wołał o nią w r. 1879 ks. Polkowski przeprowadziwszy wstępne porządkowanie zasobu ${ }^{83}$.

Tempo przekazywania akt do konsystorskiej składnicy bywało rozmaite. Kanonicy wizytujący diecezję z polecenia bpa Załuskiego w r. 1748 złożyli protokoły tej działalności z 15 dekanatów in archivo cancellariae consistorii generalis Cracoviensis $\mathrm{w}$ dniu 27 III $1751 \mathrm{r} .{ }^{84} \mathrm{~W}$ pałacu kieleckim, gdzie wielu biskupów krakowskich spędzało znaczną część życia, w 1758 r. znajdowało się 5 t. episkopaliów kard. Lipskiego z lat 1734-46, terminarze od 1744, a protocolla od 1747 r., niektóre nie oprawione, 4 t. gratiosorum Załuskiego, akta wizytacji 1748 r. z 21 dekanatów północnej części diecezji oraz producta - już niekompletne, mimo krótkiego czasu, jakiego dotyczyły ${ }^{85}$.

Archiwalia ciągle wolno napływały do Krakowa. W 1796 r. nie było tu jeszcze powstałych w Warszawie akt Poniatowskiego, zaś Acta contentiosorum Sołtyka z lat 1759-75 pozostawały nadal w Kielcach. Także pracownicy konsystorza trzymali nierzadko u siebie urzędowe akta; znaleziono je np. w 1806 r. wśród papierów pośmiertnych sufragana Olechowskiego. Po Marcinie Siemińskim, sufraganie gnieźnieńskim, byłym noțariuszu konsystorza krakowskiego, odesłano do Krakowa w 1845 r. 35 jednostek archiwalnych mniejszej wagi, głównie kopii pojedynczych akt z drugiej połowy XVIII w. i początku w. XIX ${ }^{86}$.

z XVII-XVIII w., gdzie spotyka się wzmianki o krótkotrwałym areszcie retro cancellariam $w$ przeciwieństwie do Lipowca przeznaczonego na dłuższe pobyty; por. Chotkowski, dz. cyt., 193.

82 A. Tom czak, jw., 177, 229; S. Płaza, Źródła rękopiśmienne, 174, 268.

83 Por. „Czas" nr 137 z 18 VI 1879. Wiosną 1944 r. ks. Glemma wywiózi do Zalasu k. Krzeszowic 12 skrzyń najcenniejszych archiwaliów AKK i AKM dla zabezpieczenia ich przed zbliżającym się frontem. Rękopisy umieszczono w suchej krypcie pod kościołem, gdzie znalazły się także archiwalia z kościoła Mariackiego; por. Pismo ks. Glemmy do Direktion der Archive des G.G. z 4 VII 1944 z wykazem akt (teczka Archiwum).

${ }_{84}$ Protocollum iudicii generalis Cracoviensis $1748-49$, k. I.

$85 \mathrm{Ab}$ annis pluribus decreta in variis materiis quae in terminariis suprasciptis annotantur plurima esse in productis, in iisdem productis non reperiuntur (Inventarium cancellariae Curiae episcopalis Kielcensis z 19 X 1758, poszyt dolaczony do Inwentarza z 1824).

86 Status Archivi 1796 s. 10-11; T. Glem ma, Krakowski konsystorz, 234; 
Nie zakończyło się jeszcze na dobre kompletowanie starych archiwaliów w Krakowie, a już rozpoczęła się wędrówka nowszych, związana ze zmianą granic diecezji ${ }^{87}$. W r. 1808 przejęto do Krakowa akta dotyczące przyłączonych terenów ze skasowanej diecezji tarnowskiej, oddając w roku następnym do Kielc papiery z 4 ostatnich lat, odnoszace się do terytorium tej diecezji wraz z księgami wizytacji 11 dekanatów z lat 1671 --1789 88. Przejęto także z konsystorza wrocławskiego akta dekanatów lelowskiego, pilickiego i siewierskiego, przyłączonych do tej nadodrzańskiej diecezji w okresie 1800-11. Podzielenie tego okręgu między diecezję wrocławską a krakowską w r. 1818 spowodowało kolejną ekstradycję akt z Krakowa. Po zmianie granic między diecezją krakowską a tarnowską w 1880, 1886 i 1925 r. akta dotyczące przyłączonych z powrotem parafii wracały znów do Krakowa ${ }^{89}$.

\section{PORZĄDKOWANIE AKT, INWENTARYZACJE, LITERATURA}

Bieżące potrzeby kancelarii konsystorskiej stwarzały konieczność odszukiwania priorów, co sprzyjało powstawaniu różnego rodzaju wykazów posiadanych akt. Te same jednak przyczyny powodowały selekcje regestowanego materiału, podobnie zresztą jak przy jego indukowaniu, wedle kryteriów biurowej pragmatyki. Stąd mimo dość licznych inwentarzy współczesny badacz zdany jest w niektórych sytuacjach na równie niezawodne co czasochłonne kartkowanie ksiąg.

Za najstarszy wykaz zawartości części zasobu archiwum konsystorskiego uznać należy repertorium XV i XVI-wiecznych AOf, bez tytułu, sporządzone najprawdopodobniej z końcem XVI lub początkiem XVII w. w układzie chronologicznym, współoprawne z kopiarzem regestów wcześniejszych dokumentów. Inny charakter nosi sumariusz z połowy XVII w. - Regestrum iuxta litterarum ordinem alphabeticum ${ }^{90}$. Dokonano tu podziału rzeczowego według pojedynczych instytucji kościelnych (np. katedra, kościół Mariacki, Akademia) lub ich rodzajów albo typu spraw (parafie krakowskie, pozakrakowskie, opactwa, klasztory, prebendy, tes-

pismo Konsystorza Jeneralnego gnieźnieńskiego do krakowskiego, 15 IX 1845 (teczka Archiwum).

87 Zaczątkiem archiwów nowych diecezji, tj. Lublina, Tarnowa, Sandomierza i Kielc, stały się akta byłych konsystorzy foralnych dawnej diecezji krakowskiej S. Płaza, Źródta rękopiśmienne, 227, 249, 292, 304; tamże dalsza literatura.

×r T. Gle m ma, Krakowski konsystorz, 235; Inwentarz z 1824, s. 75.

s9 Acta consistorii Vratislaviensis et comissarii episcopalis super ecclesias in decanatu Leloviensi, Pilecensi et Severiensi (Inwentarz z 1824. S. 53-56); Consignatio actorum ecclesias archipresoiteratus Częstochoviensis sub regimine vicariatus generalis in episcopati Vratislaviensis existentis ad dioecesim Calissiensem e dioecesi Cracoviensi separatas respicientium, 1799-1808 (Inwentarz z polowy XIX w.); pismo bpa Walęsi do kurii krakowskiej, 13 IX 1927 (teczka Archiwum); zob. B. Kumor, Granice metropolii, ABMK, 21 (1970), 322-338, 343-344; 22 (1971), 381.

90 Dudka, s. 1016; na czas powstania wskazuje dukt pisma i r. 1645 jako dấa ostatniej z regestowanych ksiag. 
tamenty, sprawy małżeńskie itd.), a rozeznaniu w krzyżujących się zakresach działów służyć miały oznaczenia literowo-cyfrowe, np. A 1, 2, $3, \mathrm{C} 1-5$ itp. Trzymając się w każdym dziale układu alfabetyczno-chronologicznego autor skupił się głównie na sprawach uposażenia i regestował kolejno AEp, AOf i Aadm. Z pracowitością nie szła w parze konsekwencja w rozgraniczaniu haseł, co zauważyli sami użytkownicy dzieła ${ }^{91}$.

Burzliwe losy diecezji i przesuwanie jej granic wskutek wydarzeń politycznych przełomu XVIII i XIX w., związane z tym próby rewindykacji zakordonowych dóbr kościelnych, wymagania aparatu administracyjnego gubernium lwowskiego i warszawskich komisji rządowych, dążących do rozciągnięcia dozoru nad kościelnymi instytucjami - zmuszały konsystorze do sporządzania najrozmaitszych raportów, wyciągów, zestawień, do czego potrzebowano coraz lepszej ewidencji archiwaliów.

W latach 1784-90 notariusz kurialny ks. Siemieński, przyszły sufragan gnieźnieński, sporządził spisy treści do poszczególnych tomów episkopaliów i uzupełnił współczesne ich powstaniu indeksy oraz część brakujących tytułów i nagłówków. Wykazy te choć obejmują większość spraw, nie są kompletne, gdyż urzędnik ów zestawił je wedle własnego przekonania o trwałej wartości danego aktu ${ }^{92}$. Była to więc już druga po poprzedzającej sporządzenie czystopisu selekcja. Siemieński zinwentaryzował również przechowywane w konsystorzu akta ${ }^{93}$. Status Archivi Consistorii Cracoviensis, sporządzony w 1796 r., wylicza kolejne woluminy AEp, AOf, Aadm i wizytacji. Z tego pierwszego inwentarza korzystali autorzy następnych.

Pragmatyczne założenia przyświecały również adwokatowi konsystorza Kazimierzowi Łukańskiemu, który w latach 1800-14 opracował 12 t. repertorium do AOf $\mathrm{z}$ lat 1436 -1796 i 1 t. do Aadm z 1533-$-1733^{94}$. W tym samym czasie powstały 4 t. podobnego skorowidza do AEp ${ }^{95}$. Chronologiczny układ dzieła Łukańskiego nie ułatwił zbytnio kwerendy, co skłoniło ks. Wincentego Ptaszyńskiego, notariusza konsys-

31 Connotatio haec imperfecta ac defectuosa - dopisek u dolu $k$. tytulowej, uczyniony w ostatnich latach XVIII w.

92 Zob. jego typowa uwaga, np. na początku indeksu w AEp 64.

${ }_{93}$ T. G le m ma, Krakowski konsystorz, 236.

94 Termin ad quem wyznaczyło dla AOf wspomniane na końcu dzieła zaprowadzenie w kancelarii konsystorskiej protokołów nowego typu i indeksów alfabetycznych do nich, zachowanych do dziś. Tomy Łukańskiego noszą tytuły: Index voluminum actorum Consistorii [...] lub Sinopsis [...]; w większości są datowane. a ostatni nawet dwukrotnie. Mimo to w literaturze spotyka się zarówno mylne podawanie lat powstania repertorium, jak i mianowanie pracowitego ich twórcy księdzem - Pęckowski, Józef Olechowski, 2 n.; Wypisy źródlowe do dziejów Waweiu 1440-1500, s. VII; S. Płaza, Źródła rękopiśmienne, 230; T. G lemma Krakowski konsystorz, $232-233$.

$45 \mathrm{Z}$ przepisania indeksów Siemieńskiego z poszczególnych tomów AEp. Por. Podrẹcznik archiwalny (zob. przyp. 100). 
torskiego do sporządzenia indeksu alfabetycznego do 13 t. wykazu ${ }^{96}$. Praca obu notariuszy służy badaczom do dziś umożliwiając szybkie odnalezienie większości aktów prawnych parafii (konsystorz wszak sporządzał je o wiele częściej niż kuria) z XV-XVIII w., ich bractw czy prebend oraz beneficjatów ${ }^{97}$. Ta ewidencja erekcji, uposażeń, instytuowania, rezygnacji - nie daje pełnego obrazu zawartości akt i tak przecież uwzględniających głównie prawny aspekt bogactwa życia.

W r. 1824 asesor konsystorski ks. Tomasz Świątkowski sporządził na polecenie bpa Woronicza Inwentarz Archiwum Konsystorza Jeneralnego Krakowskiego. Powtórzywszy za Status Archivi z r. 1796 dane o zamkniętych już zespołach, uzupełnił je enumeracją Protokołów. Terminarzy kancelaryjnych nawet nie próbował liczyć, a czas potrzebny na uporządkowanie stert productorum zalegających na szafach obliczał na rok ${ }^{98}$. Inwentaryzacja akt konsystorskich stante regimine Austriaco była łatwiejsza, gdyż prowadzone wtedy roczne Protocolla exhibitorum oraz alfabetyczne Indices registraturae odsyłały do odpowiednich fascykułów akt luźnych ${ }^{99}$. Materiał aktowy z lat 1818-21 podzielony został ,podług planu przez jw. Pasterza ukazanego" na działy rzeczowe, zachowane i w latach następnych:

I. Zarządzenia władz Królestwa Polskiego;

II. Korespondencja z Komisją Rządową Wyznań Religijnych i Oświecenia Publicznego;

III. Korespondencja z Senatem Rządzącym W. M. Krakowa;

IV. Korespondencja z Komisją Województwa Krakowskiego;

V. a) Pisma stron; b) Opisy parafii i wizytacje dziekańskie; c) Inwentarze kościelne; d) Rachunki administracji funduszem kościelnym;

VI. Sprawy zamiany dziesięcin;

VII. Akta dotyczące supresji klasztorów w Królestwie Polskim.

96 Index alphabeticus ecclesiarum et aliarum piarum fundationum, quarum iura in regestro [...] per Eukański confecto specificantur. Hasłami są nazwy parafii w porządku alfabetycznym (oprócz katedry, kolegiat i kościoła Mariackiego, wyliczonych na początku na zasadzie precedencji), po których następuje łacińska numeracja tomów i arabska kart repertorium Łukańskiego. R. 1806, podany jako data sporządzenia indeksu, dotyczy gotowych wówezas woluminów tego ostatniego (t. 1-8). Zmiany atramentu i nierówność niezapisanych miejsc potwierdza sukcesywne uzupełnianie wykazu przez Ptaszyńskiego i jego pomocnika Martyńskiego.

${ }_{97}$ W AKM znajduje się jeszcze Index ecclesiarum aliarum dioecesum, quorum iura in Indice Eukańsciano exhibentur. Jego treść $\mathrm{w}$ minimalnym tylko stopniu odpowiada tytułowi, gdyż wyliczywszy po kilka kościołów w innych diecezjach, wymienia klasztory i kolegiaty diecezji krakowskiej.

98 Reperiuntur insuper terminariorum libri complures et producta ex variis retro annis in fasciculis ligata et simpliciter in summitate armariorum locata sed priorum nullus est usus, documenta vero vix spatio unius anni segregari et consignari possunt (s. $58-63,74)$.

${ }_{99}$ Tamże, s. 32-41. Istniał także wówczas do dziś zachowany Rejestr papierów sub numero $w$ plikach zostających wyliczający zawartość 128 wiązek akt z $1766-81$. 
Pozostałe akta ułożono w wiązki wg parafii.

Opracowany około połowy XIX w. sekstern Podręcznik archiwalny Archiwum Konsystorza Krakowskiego zawiera wykaz tradycyjnych serii akt, poprzedzony rodzajem przewodnika topograficznego ułatwiającego odnalezienie na półkach poszczególnych grup ksiag ${ }^{100}$. Podając liczbę woluminów wizytacji na 87, autor stwierdził brak niektórych tomów w porównaniu $z$ Inwentarzem Świątkowskiego.

Wydana drukiem charakterystyka zasobu archiwum konsystorskiego ukazała się w pracy Bedy Dudika w 1867 r.101 Benedyktyn ów, który w 10 tygodni dokonał lustracji 35 archiwów galicyjskich, poświęcił także kilka dni na przejrzenie zbiorów przy ul. Kanoniczej. Odnotowawszy stan liczebny zespołów, zauważył istniejące luki w seriach woluminów, a zasób scharakteryzował pobieżnie i niedokładnie. O wiele lepszej klasyfikacji, ułatwionej istnieniem omówionych wyżej inwentarzy, dokonał w 1879 r. podkustoszy katedralny ks. Ignacy Polkowski ${ }^{102}$. Na tych dwu opracowaniach oparł się autor przewodnika po polskich archiwach, Edward Chwalewik ${ }^{103}$.

Pierwszym i dotąd jedynym drukowanym wykazem części zasobu AKM jest katalog zmikrofilmowanych przez Ośrodek ABMK z Lublina na początku lat 60-tych i 70-tych 218 jednostek archiwalnych. Obejmuje on 123 tomy akt wizytacyjnych, 87 - episkopaliów do 1754 r., 4 - repertorium do AEp, 3 - korespondencji bpa Soltyka $\mathrm{z}$ gubernium, 1 spis ludności z 1786 r. ${ }^{104}$.

Podsumowanie starszej literatury o zasobach AKM i danych $z$ nowszych wzmianek, pochodzących głównie ze wstępów do wydawnictw źródłowych, stanowi fragment wydanej w 1976 r. cennej pracy Stanisława Płazy ${ }^{105}$.

100 Date powstania Podręcznika określa wzmianka o 30 t. indeksów do Protocollum exhibitorum zachowanych nieprzerwanie do $1852 \mathrm{r}$.

101 Archive in Königreiche Galizien, ,Archiv für Österreichische Geschichte" 39 (1867), 46-49.

102 Por. .Czas" nr $136-139$ z $17-20$ VI t. r.

103 Zbiory polskie, t. 1 Warszawa 1936, 187-188.

104 Kat. mikr. nr 1, 85-86; nr 4, 285-314.

105 Źródła rękopiśmienne, 229-234. 


\section{ARCHIVES OF THE METROPOLITAN CURIA IN CRACOW}

\section{S U M M A R Y}

The oldest archival fund in the A.M.C. form Act: official - Acta officialia (1410-1796, 206 v.) and episcopal - Acta episcopalia (1466-1800, 116 v.). First came into existence in Cracow resulting from the activities of the general consistory, secondly in the bishop curia situated in the place of his temporaty stay.

They both contain the administrative and tribunal groundwork and therefore form the institution called the Church (parish, chapel, hospital, canonry, etc.) donations for these, beneficiary of the institution, testamentory matters, marital, penalty (particulary clerical), oblates. Administrative Acts - Acta administratoralia $(1533-1759,28$ v.) which have been left by those who ruled the dioeceses being vacant are of similar nature. There are still left many rough copies of the three kinds of books making main class in the A.M.C. as well as several hundred fascicles of so called Producta i. e. enclosures (various affidavits, writs, official records of examination of witnesses, letters, etc.).

One of the largest Polish collection of official records of bishops inspections made either by themselves or by their substitutes kept in the A.M.C. refers to the period between 1565 and 1795. It contains rich sources to make a study religions life and sacral art and many other problems. The earliest bishop Padniewski inspection (1565-1570) includes 328 churches in Cracow dioecese consisting of ca. 1000 parishes. Card. Radziwiłł inspection (1595-1599, 13 v.) includes 916 churches and bishop Zaluski inspection (1746-1748, 21 v.) includes 753 parishes. In orders register dates from 1575.

Up to the XIX ${ }^{\text {th }} c$. the records we're talking about were situated in the archive repository near by the consistory office in Kanonicza St. inside the building bought from Jan Dlugosz in 1460. The oldest parchment documents are stored in the Archives of the Metropolitan Chapter in Wawel. In the years 1796 and 1824 a list of the inventory of consistory archives aws made. From 1800-1814 Kazimierz Eukański was making a catalogue of Acta episcopalia (4 v.), officialia (12 v.) and administratoralia ( $1 \mathrm{v}$.$) .$

In the $\mathrm{XIX}^{\text {th }}$ and $\mathrm{XX}^{\text {th }}$ cc. the documents (mainly fascicles) were set in chronological and subject order. There are also day books and their year indexes that concern the period. A part of documents concerning the end of the XVIIIth c. and the $\mathrm{XIX}^{\text {th }} \mathrm{c}$. was exhanged by neighbouring dioeceses while they were changing their frontiers. Records of the XIXth-XXth $c c$, earlier unifixed documents and single books that do not belong in any cathegory under consideration in this paper must be listed according a modern standard. 